\title{
Breaking the Glass Ceiling: the Role of the UN and the EU in Promoting Women in Politics
}

\author{
RUŽICA JAKEŠEVIĆ, ĐANA LUŠA \\ Faculty of Political Sciences, University of Zagreb
}

\begin{abstract}
Summary
Politics has traditionally been reserved for men, meaning it has been very difficult for women to enter at the highest level. The progress in gender equality in politics has been uneven so far and significant differences exist among states and regions. The male dominance in state politics has translated into the international realm in international entities and multilateral political platforms as well. Although these entities gradually introduced the principles of gender equality and promoted an increased participation of women in political life in their constituent states through key documents, they face the same problem how to ensure at least a formal and descriptive representation of women at the highest level and how to translate stated or symbolic gender equality from key documents into practice (symbolic to substantive representation). The aim of this paper is to give an overview of the historical development of the international framework for the equal participation of women in politics. Particularly, this paper analyses how two international entities - the UN and the EU - contribute to overcoming the gender-gap in politics, and whether their activities have influenced an increased participation of women in politics (descriptive representation).
\end{abstract}

Keywords: Women in Politics, Political Participation, Gender Equality, Descriptive Representation, EU, UN

\section{Introduction}

Throughout human history, political units worldwide have been prone to grant different treatment to people depending on their biological and social characteristics, while firmly fixed social and cultural backgrounds and practices create an important context that enables such developments (Wood \& Eagly, 2015; Eagly \& Wood, 2013). The problem arises when the fact of biological differences, as well as constructions such as "appropriate roles" for men and women are used as a basis for 
creating policies which prevent equal treatment in different spheres of social life. These spheres include the whole range of entitlements, from personal, to social and professional ones - from the basic personal integrity and family life, through access to education, the right of inheritance, to the right of participation in the political life of their communities, to name just a few. In each of these spheres, masculinity and femininity were strictly assigned to men and women, whereby the former was predominantly associated with characteristics such as strength, power and rationality (Tickner, 1992), while the later 'embodied' weakness, sensitivity and feelings, or as Guerrero Witt and Wood put it "according to gender stereotypes, men, more than women, are agentic - that is, masterful, assertive, competitive, and dominant" while "women, more than men, are communal - that is, friendly, unselfish, concerned with others, and emotionally expressive" (Guerrero Witt \& Wood, 2010, p. 635). The aim of this article is not to theorise about the meaning and definitions of gender, since it focuses strictly on the role of women in politics, especially in the context of the gender gap as an unfavourable ratio of women to men.

One does not have to reach far into history to observe women's unequal access to politics in terms of active and passive voting rights, since the $20^{\text {th }}$ century provides plenty of examples, including those in democratic political orders, where women were faced with exclusionary policies which prevented their political participation (Ravi Kumar, 2002; Tremblay, 2007; Stockemer, 2007). ${ }^{1}$ Even today, there are significant regional differences in terms of how and if women participate in political life, varying from the Swedish concept of "feminist foreign policy" to the almost complete ban on political participation of women in Saudi Arabia, where they were given the opportunity to take part in municipal elections for the first time in 2015 (Human Rights Watch, 2015). Even in the Roman Catholic Church women have traditionally been "consigned to the shadows of its administration" (NBC News, 2020). This started to change at the beginning of 2020 when Pope Francis named the first woman to hold a high-ranking post in the Secretariat of State (effectively one of two deputy foreign ministers) (Ibid.). Whether and how women will participate in political life thus varies depending on different political systems, ideologies and religious settings, while the argument that democracy is inextricably linked to equal participation of women in politics, at least nominally or in theory, is

1 For example, in 1900 no women had been elected or appointed to a national legislature. In 1907 Finland became the first country to elect women to parliament, while the Union of Soviet Socialist Republics was the first to reach 10\% women in its national legislature in 1946 (Paxton $\&$ Hughes, 2019). During the 1980s only six women served as their nations' head of state and by the 1990s this number increased to 16 (George, 2019). All until 1991 women were not allowed to vote in cantonal elections in the Swiss canton of Appenzell Innerrhoden (Swiss Fact, 2017), while it was only in 1971 that women could vote at federal elections in that country (Lloren, 2019). 
widely accepted (Tremblay, 2007; Stockemer, 2007; Zungura, Nyemba, Mutasa \& Muronza, 2013; UN Women, 2018a).

All until the mid- $20^{\text {th }}$ century, women were almost completely excluded from diplomatic practice and in the majority of states were considered inappropriate diplomatic agents - their gender as such, as well as deeply rooted beliefs of how women act, behave and think and how they would be able to cope with challenges within the political arena, disqualified them completely (Foreign and Commonwealth Office, 2018).

One of the leading authors of the theory of diplomacy, Abraham de Wicquefort in the $17^{\text {th }}$ century, saw women assisting in the running of diplomatic affairs, but not being ambassadors (Ibid.). Niccolò Machiavelli, the pioneer of diplomatic theory and practice, emphasised the importance of masculine characteristics in conducting state relations. In addition, diplomat Sir Harold Nicolson expressed his doubts, stating that "women are prone to qualities of zeal, sympathy and intuition which, unless kept under the firmest control, are dangerous qualities in international affairs" (Rahman-Figueroa, 2020). Diplomacy started to open for women in the 1920s, however a century later according to Towns and Niklasson (2017) 85\% of the world's ambassadors were men. ${ }^{2}$ Asked in 1933 whether the Diplomatic Service should be open to women, ambassadors of the day stated their disapproval: it was "inadvisable", "unthinkable" or even "criminal". One even wrote that it was "impossible" to conceive of women having babies and a diplomatic career. Another explained that "clever woman would not be liked and the attractive woman would not be taken seriously" (Rawlings, 2016). ${ }^{3}$

Only in the $20^{\text {th }}$ century things started to change and women began to be appointed to diplomatic positions as a regular practice. In 1933, 13 countries accepted women to Diplomatic and Consular Services (Ibid.), with Spain acting as a pioneer by appointing Isabel de Zulueta as Chancelier of the Spanish legation in Panama in 1933 (Fritsche, 2002). At that time US Foreign Service was convinced that women

${ }^{2}$ When it comes to women in diplomacy, the data show the increasing number of women in political life at different levels. According to Towns and Niklasson (2017, p. 521) "Women now make up $25-40 \%$ of the ambassadors of a number of states, such as Finland (44\%), the Philippines (41\%), Sweden (40\%), Norway (33\%), the United States (30\%), Canada (29\%), Colombia $(28 \%)$. The Nordic countries have the largest proportion of female ambassadors, $35 \%$, followed by North America at $25 \%$, Europe, South America and Africa with $15 \%$. Asia and the Middle East are below the average with 10 and 6\%" (Ibid.).

${ }^{3}$ After the Congress of Vienna, diplomacy becomes more prominent with wives of ambassadors playing a role "in the shadow of their husbands". Their qualities in social life were taken into consideration when their husbands were nominated for ambassadors. Through their engagement women of that time tried to "subsequently exert pressure on diplomatic positions" (Demel, 2017). 
"were not fitted to discharge the exacting and peculiar duties of a Foreign Service Officer". ${ }^{4}$ This unfair treatment of women in Foreign Service started to change at the beginning of 1940 because of the unprecedented personnel needs during World War II (Wood, 2015). President Roosevelt named Ruth Bryan Owen as the first female chief of mission of the U.S. Embassy for Denmark and Iceland, while the Soviet Union appointed its first female chief of mission ten years earlier. President Truman appointed the first chief of mission at the ambassador level in 1949 (Helen Eugenie Moore Anderson to Denmark). However, until president Ford the number of female appointments as chiefs of mission or assistant secretaries of state stayed within the single digits. The rapid progress began with the Carter administration; namely 18 women were made chiefs of mission and 10 were appointed to other senior posts (Vagnoux, 2015). Although the male dominance in diplomacy dates far back in time,${ }^{5}$ the share of women diplomats has shown an upward trend since the late 1990s.

Likewise, security related issues, whether in national or international domains, such as creating security policies, decision-making or the composition of parts of security systems and peace operations, have traditionally been considered a part of a "high politics" agenda and thus there was little, if any, space for the effective participation of women. According to J. Ann Tickner, the widespread belief is that "military and foreign policy are arenas of policy-making least appropriate for women" (Tickner, 1992, p. 2). Traditional realist ideas of security, which focus on the concept of national security with the state as the referent object and external (military) threats have for a long time dominated European and global politics, and as such have not provided any space for critical thinking on how such a narrow conception of security affects different parts of society, let alone women. This has led some authors to conclude that "traditional approaches to security have been inadequate, substantively and methodologically" (Hudson, 2010, p. 5). With the "widening and deepening" of the security agenda, the introduction of sectoral analysis (Buzan, Wæver \& de Wilde, 1998; Krause \& Williams, 1996) and the emergence

${ }^{4}$ They were not supposed to take credits for their contribution to the operation of diplomacy. Their role was very important, they hosted dinners, accompanied their husbands to their social functions, and facilitated the exchange of information. In reports on the work of their husbands, they were also mentioned. Soon with the increase in the complexity of duties in the embassies, some chiefs of mission began to hire their wives as clerks (Wood, 2015).

${ }_{5}^{5}$ During 1946, women in the UK were also given the opportunity to become career diplomats, however their prohibition from marrying was not lifted until 1972. In Ireland, a diplomatic career was open to women after the war with the first ambassador named in 1950. In Spain, the ban of recruiting female ambassadors was lifted in 1962 with first ambassador appointed in 1971. In Italy exams for access to a diplomatic career were opened in 1963, while the first French female ambassador was appointed in 1972. The first female Hungarian Ambassador was appointed in 1974 (Demel, 2017). 
of critical approaches to security, as well as the growing prominence of peace and gender studies, the concept of human security has gained strength. This means that the possibilities for the introduction of new referent objects (what or who is to be secured) and actors (decision-makers) have been broadened, which has resulted in increasing opportunities for the inclusion of a gender dimension into security studies and security practices.

With that mentioned, long-term practices, which were based on the assumptions of appropriate social roles for men and women, have informed policies well into the $20^{\text {th }}$ and $21^{\text {st }}$ centuries, and despite the progress achieved in normative terms and a formal representation throughout the past several decades, the "gender gap" is still present in politics. Therefore, this paper aims to give an overview of the historical development of the international framework for the inclusion/equal participation of women in politics as well as to determine whether at least the descriptive representation has been achieved at the highest levels. For that purpose, we will provide an assessment of how two international entities - the EU and the UN - contribute to overcoming the gender-gap in politics, in terms of legal framework and its implementation on gender equality, backed by research on the number of the highest positions occupied by women (descriptive representation). Aware of the fact that an analysis of these two entities does not present a comprehensive research on gender equality in politics, as well as that descriptive representation is mostly about numbers and not about concrete policies resulting from it or the motivations behind the low participation of women in politics, the paper aims to selectively contribute to the study of women representation in politics. The United Nations has been chosen because of its global membership, therefore presenting most of the world in most of its diversity, while the European Union can be considered a forerunner and leading multinational entity in terms of promoting gender equality in politics.

\section{Conceptual Framework: the Political Representation of Women}

Political representation presents a core topic in the research of women in politics. Women's exclusion from spheres of political decision-making results with their interests being overlooked. Political exclusion also results in women not being able to contribute to the political process (Childs \& Krook, 2008). According to Paxton and Hughes (2019) there are two different types of arguments that are used to justify women's political representation. First, there are justice arguments according to which women constitute about half of the population in every country and therefore they should also present half of elected or appointed leaders. Then there is a line of thinking based on the usefulness of having women in politics. According to this utility approach emphasizing the difference women's representation makes, "women's presence is expected to change politics or society in some way" (Ibid.). 
Pitkin (1967, p. 61) identifies four dimensions of political representation: 1) formal representation, referring to the "institutional rules and procedures through which representatives are chosen"; 2) descriptive representation, referring to the "compositional similarity between representatives and represented"; 3) substantive representation, referring to the "congruence between representatives' actions and the interest of represented"; and 4) symbolic representation, referring to the "represented's feelings of being fairly and effectively represented". If we go back into the past, the very first arguments for women's representation called for "women's formal representation or the right to participate in politics" (Paxton \& Hughes, 2019, p. 36) alongside men. Formal representation means that "women and men should be offered the same opportunities to participate in politics" (Ibid.). The problem is that allowing women to participate on an equal basis does not mean that the result will be sizeable numbers. Arguments for women's representation, which are based on the symbolic realm, articulate the idea that female political leaders usually act as role models for young girls and women and may have transformative effects by sending a message to men and boys that women are fit to rule (Ibid.).

The literature on women in politics suggests two major perspectives on political representation: descriptive and substantive. The main distinction is whether the focus is on the "number of women elected" (descriptive) or the "effects of women's presence in political structures" (substantive) (Wängnerund, 2009, p. 52). Although these two perspectives are interconnected, according to Wängnerund (Ibid.) they have distinct sets of theoretical reasoning and tools for doing empirical research.

Pitkin (1967) defines descriptive representation as the make-up of a legislative body. To put it more simply, it means "the number or proportion of women" (Lore, 2016, p. 6). Faced with the slow pace of change in the number of women entering politics during the $80 \mathrm{~s}$ and $90 \mathrm{~s}$, feminist political theorists began to focus on women's presence in politics (Young, 1990; Sapiro, 1982; Mansbridge, 1999), calling for elected bodies to share key characteristics with the citizens who elected them. For example, if women make up half of the population there should be half of the seats reserved for them in legislative bodies. Though the arguments brought forward by justice representation, that women have the right to be represented in equal number as men, are compelling, descriptive representation matters more "because women and other marginalized groups are thought to be uniquely suited to represent themselves in political institutions" (Paxton \& Hughes, 2019). This is clearly stated in the 1995 UN Beijing Platform for Action: "Women's equal participation in decision making is not only a demand for simple justice or democracy, but a necessary condition for women's interests to be taken into account" (UN, 1995, p. 79).

The substantive perspective focuses on how the growth of women's representation in a parliament makes a substantive difference, having in mind that men and 
women have different experiences and priorities in politics (Ibid.). In this case one of the key questions is "whether women's increased presence in national legislatures would result in improved representation of women's interests and policy areas which are of direct concern to women" (Iwanaga, 2008, p. 4). This approach implies that female politicians have "a gendered awareness", a shared experience and perspective that unites them based on their gender (Ibid.). Pitkin (1967) claims that standing for is not the same as acting for, meaning that politicians need to speak for women's interests and act to support women's issues. There is a lot of research showing that women have different policy priorities than men (Swers, 1998; Chattopadhyay \& Duflo, 2004). This sometimes results with initiating and passing laws that serve women's and children's interests. However, there are several complexities related to the research on substantive representation, such as the way parliaments function as institutions or what will an increased number of women in parliament mostly affect: policy outcomes or maybe internal working procedures (Wängnerund, 2009).

Research on descriptive representation, applied in this paper, enables us to draw some conclusions based on data on the numerical distribution of positions between men and women in different countries, regions and particularly in two examined entities in different periods. According to Wängnerund (Ibid.), in order to analyse numeric differences or numeric changes over time, far-reaching definitions of women's interests are not necessary. For example, it is acceptable to use the share of seats in a parliament as an indicator of political inclusion in society for a category such as women. Therefore, in this paper our focus is on explaining what concrete numbers of women at the highest positions in two analysed entities mean for the equal representation of women in politics generally. On the other hand, in studies focusing on substantive representation one needs to specify a concept such as "women interests" and to "answer the question about the extent to which an increase in the number of women elected affects how societies function" (Bühlmann \& Schädel, 2012, p. 103). This surpasses the aim of this paper.

An overview of the numerical trends within the EU and the UN, as well as a qualitative analysis of key strategic documents are used in this paper. By presenting these numbers, we are aware of the fact that the distinctive behaviour of women in politics does not depend only on increasing the percentage of women representatives, nor that an increase in the number of women will immediately translate into policy gains for women. According to Lore (2016) there are many other variables such as party affiliations, institutional norms, legislative experience and the external political environment, which also surpass the aim of this paper. 


\section{Women and Gender Equality in Politics}

Looking back into history, one can see that the dominant "male" realm of politics for centuries was almost completely sealed off from women. For example, the right of female descendants to inherit the throne in special circumstances (in the absence of direct male descendants) presented a point of contention in and among European monarchies. ${ }^{6}$ The first country to introduce principles of gender equality in this respect was Sweden, when in 1979 "absolute primogeniture" was introduced, thus changing the Act of Succession (1810), which regulates the line of succession to the Swedish throne. ${ }^{7}$ By enacting this law, Sweden became the first European monarchy to officially adopt absolute primogeniture and paved the way for others to follow suit. Such changes were made in the Netherlands (1983), Norway (1990), Belgium (1991), Denmark (2009) and Luxembourg (2010) (Corcos, 2012) and the UK (2015), while male preference primogeniture is still practiced in Spain in line with section 57(1) of the 1978 Constitution (Agencia Estatal Boletín Oficial del Estado, 1978) and Monaco (Journal de Monaco, 2002).

In the modern age, Sweden is again pushing the boundaries in terms of the promotion of equal rights, regardless of gender, in decision-making and the inclusion of women in leading positions in the government. As of 2019 it officially defines its government as the "feminist government" which concentrates on removing all the obstacles to gender equality, as a human right, in creating state policies and in conducting its international affairs (Government of Sweden, 2019a). Gender equality has been at the heart of its foreign policy since 2014, when "Sweden became the first country in the world to launch a feminist foreign policy"s (Government of Sweden, 2019b, p. 6) - which is described as "standing against the systematic and global subordination of women" and a "precondition for achieving Sweden's wider foreign development and security policy objectives. Gender equality is a right on its own, (...) and is also the most effective means for achieving other goals, such as the

${ }^{6}$ When in 1713 the Pragmatic Sanction was promulgated by the Holy Roman emperor Charles VI, stipulating, among other things, "that his undivided heritage go to his eldest son, should he have one, or, failing a son, to his eldest daughter and then, if she should die without issue, to his deceased brother Joseph I's daughters and their descendants" - Charles VI had to invest a lot into his diplomacy whose aim was to persuade other European powers to accept this decree. Although it was nominally accepted by the dominant powers (Russia, Prussia, Spain, the Netherlands, Great Britain or France), the Pragmatic sanction was contested immediately after Charles VI's death in 1740, resulting in the War of Austrian Succession, which led to some territorial losses, but leaving Charles VI's daughter Maria Theresa on the throne (Britannica, 2019).

7 The introduced changes in Article 1 stipulated that "both male and female descendants of Carl XVI Gustaf have the right to succeed to the throne" (Sveriges Riksdag, 2016).

8 The term and the concept has been popularised since 2014 by the Swedish Foreign Minister Margot Wallström. 
eradication of terrorism, economic growth, and improvement in health" (Thompson \& Asquith, 2018). By such moves, Sweden not only promotes gender equality as the goal itself, but also the idea and the belief that gender mainstreaming can bring about positive impact in terms of achieving overall political objectives. Currently (December 2020), its 22-member Government office consists of 10 men and 12 women, who lead ministries such as finance, foreign affairs, employment, education or gender equality (Government of Sweden, 2020). Canada under the government of Justin Trudeau is another country that has introduced gender equality aspects across different sector policies, including foreign policy, security and social affairs (OpenCanada.org, 2019). Sweden and Canada, together with Norway, can be considered the global leaders in promoting gender mainstreaming in informing and creating foreign and security policies (Aggestam, Bergman \& Kronsell, 2019; Chapnick, 2019).

Today, the political practice of many countries, international organisations and security alliances is nominally open to women on an equal basis as it is to men. Some of them have put the issues of gender equality on their agendas to narrow the gap between men and women in terms of basic human rights, political participation, the right to education, economic and social rights, including income equality. The second half of the $20^{\text {th }}$ century saw the development of international norms aimed at alleviating and eliminating any obstacles to gender equality, which were subsequently incorporated into the national legislation of the majority of existing countries. ${ }^{9}$ However, the theory and practice of these entities frequently do not go hand in hand, and the world has rarely seen the highest positions occupied by women in the case of international entities, organisations and alliances, such as the United Nations, the EU or NATO, or the most powerful countries in the world, which are permanent members of the UN Security Council (the US, the Russian Federation, China, France, with the exception of the United Kingdom).

Generally, it is fair to recognise that the situation has improved significantly during the last few decades, with the increasing number and percentage of women in politics (nationally, regionally and globally). For example, twenty years ago (1999-2000), "9 women were Heads of State or Government. In 1998, 8\% of the world's cabinet ministers were women, compared to $6 \%$ in 1994 . Sweden was, in 2000 , the only country with most women ministers $-55 \%$. Worldwide, more progress has been made in the appointment of women to sub-ministerial positions, particularly in the Caribbean and the developed regions outside of Europe, where

9 Such as: the 1945 Charter of the United Nations; the 1948 Universal Declaration of Human Rights; the 1966 International Covenant on Civil and Political Rights; the 1979/1981 Convention on the Elimination of All Forms of Discrimination against Women (CEDAW); the 2013 Declaration of Commitment to End Sexual Violence in Conflict, and others. 
women hold approximately $20 \%$ of sub-ministerial positions. (...) In 1999 , women represented $11 \%$ of parliamentarians worldwide, compared to $9 \%$ in 1987 . Women's representation, on average, was highest in Europe (21\%) and in the developed regions outside Europe (18\%). Only the Nordic countries and the Netherlands have at least one third women parliamentarians" (Fritsche, 2002).

According to the Inter-Parliamentary Union (IPU) and UN Women, in 2020 the above-mentioned categories were as follows:

- there were 10 (out of 152) female Heads of State ${ }^{10}$ or $6.6 \%$ and 12 (out of 193) female Heads of Government ${ }^{11}$ or $6.2 \%$ (in total 20 women, since in Bolivia and Switzerland head of state serves as the head of government as well);

- among cabinet ministers, only 14 countries had at least $50 \%$ female ministers, ${ }^{12}$ while 139 out of 190 countries had less than $30 \%$ of women in ministerial positions in 2020. Among the EU27, differences span from very low presence of women in ministerial positions in Lithuania (7.7\%) to $66.7 \%$ in Spain. It is interesting to note that, out of 1451 portfolios held by women in 190 countries, there were 60 female foreign ministers, 22 defence ministers and 27 ministers of economy, while the highest percentage of women held portfolios such as social affairs, family/children/youth, environment or employment;

- women accounted for 57 out of $278^{13}$ speakers of parliament or $20.5 \%$. There were also $24.9 \%$ female parliamentarians worldwide. Regionally, representation of women in parliaments is distributed as follows: Nordic countries, 43.9\%; Americas, 31.3\%; Europe including Nordic countries, 29.9\%; Europe excluding Nordic countries, 28.8\%; sub-Saharan Africa, 24.4\%; Asia, 20\%; Middle East and North Africa, 16.6\%; and the Pacific, 19.4\% (IPU and UN Women, 2020).

According to the Pew Research Center, "Fifty-six of the 146 nations (38\%) studied by the World Economic Forum in 2014 and 2016 have had a female head

10 Bolivia, Estonia, Ethiopia, Georgia, Nepal, San Marino, Singapore, Slovakia, Switzerland, Trinidad and Tobago.

11 Bangladesh, Barbados, Belgium, Bolivia, Denmark, Finland, Germany, Iceland, New Zealand, Norway, Serbia, Switzerland.

${ }^{12}$ Spain (66.7\%), Finland (61.1\%), Nicaragua (58.8\%), Colombia (57.9\%), Austria (57.1\%), Peru (55\%), Sweden (54.5\%), Rwanda (53.6\%), Albania (53.3\%), France (52.9\%), Andorra (50\%), Canada (50\%), Costa Rica (50\%) and Guinea-Bissau (50\%).

${ }^{13}$ Both lower and upper houses of parliaments are included, depending on the political systems, as well as cases where there is more than one speaker (two or three). 
of government or state for at least one year in the past half-century" (Geiger and Kent, 2017). Hence, in global terms, there has been gradual but slow improvement.

However, many countries in the world, including the most developed ones, still have to take additional measures in their policies and to show political will to be able to follow the Nordic countries, which are the leading nations in gender equality in a variety of areas.

\section{The EU and Gender Equality in Political Participation}

The EU, as one of the international entities analysed in this paper, has a very developed structure across all its institutions for improving the gender balance in a number of areas, including political decision-making. Starting from the Treaty of Rome ${ }^{14}$ (1957) establishing the European Economic Community, the European Union has promoted the concept and policy of gender equality as one of the key values for the future development of the Union (European Commission, 2017). At that point, the equality principle was introduced through Article $119,{ }^{15}$ which required equal pay for equal work regardless of sex (Beck, 1978). Over decades, the equality between men and women principle has informed EU policies, legislation and institution-building, resulting in the creation of the DG JUST as the Commission department responsible for justice, consumers rights and gender equality in 2010 (DG JUST, 2019). ${ }^{16}$ Article 8 of the Treaty on the Functioning of the EU (TFEU) presents the basis for the elimination of inequalities in all the EU activities, and although not specified precisely, it can be considered a basis for practicing gender equality also in terms of the political participation of women. Furthermore, Article 19 of the TFEU provides the Council with an opportunity to take actions to combat discrimination based on sex "acting unanimously in accordance with a special legislative procedure and after obtaining the consent of the European Parliament" (Official Journal of the European Union, 2016). Within the ordinary legislative procedure, the Parliament and the Council "may adopt the basic principles of Union incentive measures, excluding any harmonisation of the laws and regulations of the Member States" as a supportive action to member states in fulfilling the goal of eliminating any discrimination

14 This treaty has undergone changes through decades with the institutional development of the EU and today it is known as the Treaty on the Functioning of the EU.

15 It was the basis for the current Article 157 of the Treaty on the Functioning of the EU. Additionally, Article 8 stipulates that: "In all its activities, the Union shall aim to eliminate inequalities, and to promote equality, between men and women" (Official Journal of the European Union, 2016).

16 Under the Barroso Commission, in 2010 DG for Justice, Freedom and Security was split into two separate DGs: DG Home Affairs and DG Justice, Fundamental Rights and Citizenship. Under the Juncker Commission, in 2014 the portfolio was renamed into Justice, Consumers and Gender Equality (DG JUST, 2019). 
based on sex (Ibid.). Besides the TFEU, Treaty on European Union states equality between men and women as one of the common values of its member states (Article 2) that shall be promoted (Article 3) by the Union (Official Journal of the European Union, 2012a). This course of action shows that the EU gradually moved from the general principle of non-discrimination to promoting an active approach towards overcoming the systemic disadvantages that women were faced with through decades and centuries which resulted in gender-gaps in many spheres of social life, including politics and leadership (European Parliament, 2019a). In terms of the applied conceptual framework in this paper, this means a shift from descriptive (presence in terms of numbers) to substantive representation (the impact of presence). Apart from the Treaties, current EU legislation on gender equality is derived also from the EU Charter on Fundamental Rights. Hence, broadly speaking, the EU gender equality acquis encompasses relevant provisions of the EU Treaties and of the Charter on Fundamental Rights, ${ }^{17}$ legislation ${ }^{18}$ and the relevant case law of the Court of Justice of the EU (CJEU) (Senden \& Timmer, 2019).

Despite being rooted in the foundations of the EU, gender equality and gender parity (a 50/50 percent ratio between women and men) have not yet become the regular practice in the EU's institutions and in the institutional setting of its member states. According to the European Institute for Gender Equality (EIGE), in 2020 the EU's Gender Equality Index score was 67.9 out of $100,{ }^{19}$ an increase of only 4.1 points since 2010 (EIGE, 2020). In the period between 2017 and 2020 the same source states that the increase was only $0.5 \%$ and that at this pace it will take the EU 60 years to achieve gender equality (Ibid.). The progress has been slow and significant discrepancies still exist between member states, with Sweden (83.8), Denmark (77.4) and France (75.1) showing the highest Gender Equality Index value, while

17 Article 21 (Non-discrimination) and 23 (Equality between men and women) of the Charter.

18 Currently, the EU legislation on gender equality includes the following directives: 1. Directive on the implementation of the principle of equal opportunities and equal treatment of men and women in matters of employment and occupation (2006/54/EC); 2. Directive on the implementation of the principle of equal opportunities and equal treatment of men and women in matters of employment and occupation (2006/54/EC); 3. Directive on equal treatment of men and women in statutory schemes of social security (79/7/EEC): 4. Directive on the implementation of the principle of equal opportunities and equal treatment of men and women in matters of employment and occupation - Recast Directive (2006/54/EC); 5. Directive on the application of the principle of equal treatment between men and women engaged in an activity in a self-employed capacity (2010/41/EU); 6. Pregnant Workers' Directive (92/85/EEC); 7. Directive implementing the revised Framework Agreement on parental leave (2010/18/EU); 8. Directive on equal treatment of men and women in the access to and the supply of goods and services (2004/113/EC).

19 EIGE uses the scale from 1 (total inequality) to 100 (total equality) to measure the gender gap in six main domains in each EU member state and the EU as a hole. These six domains are: work, money, knowledge, time, power and health. 2020 Gender Equality Index included the UK. 
Romania (54.4), Hungary (53.0) and Greece (52.2) hold positions on the bottom of the scale. Out of six domains that constitute the Gender Equality Index, "gender inequalities are most pronounced in the domain of power ${ }^{20}$ (53.5 points)" (Ibid.), despite the fact that the biggest improvement has been made precisely in this area since 2010, while gender equality is considerably higher in domains of health (88) and money (80.6). Sweden, Finland and France show the highest scores in the subdomain of political power (parliaments, ministries, regional assemblies), while the lowest scores were recorded in Hungary, Cyprus and Malta. Overall, during the stated period, the scores regarding gender equality in the political power sub-domain decreased in two member states - Slovenia and Romania since 2017 (EIGE, 2020).

Similarly, the Special Eurobarometer Report requested by the DG JUST in 2017 to assess gender equality in the EU28, shows that $91 \%$ of respondents think that promoting gender equality is important for ensuring fair and democratic societies, while on the other hand approximately half of respondents ${ }^{21}(51 \%)$ think that gender equality has been achieved in politics. At the same time, $69 \%$ of them believe that "women are more likely than men to make decisions based on their emotions" (European Commission, 2017, p. 4). One of the main conclusions of the survey is that the majority of the EU public supports the idea that there should be more women in political decision-making positions, with $70 \%$ of respondents who contend that gender parity should be legally prescribed. More precisely, $61 \%$ believe that politics is dominated by men who are not confident enough in women, while $67 \%$ think that women are less free because of their family responsibilities, which can be considered one of the obstacles to increased female political participation. The following numbers are additionally, and particularly worrying: $35 \%$ of respondents think that women are less ambitious than men, 34\% think that women are less interested then men in positions of responsibility in politics, while $17 \%$ think that women do not possess the necessary qualities and skills for such positions (Ibid.).

Some of these arguments are reflected in the EU Gender Equality Strategy 2020-2025 which presents a continuation of the previous Commission's work in line with the European Commission's Strategic engagement for gender equality 2016-2019, the Strategy for equality between women and men 2010-2015 and the Council's European Pact for Gender Equality 2011-2020. The Commission's work in this area rests upon several priority areas ${ }^{22}$ including equality in decision-mak-

20 The domain of power is measured across three categories: political, economic and social.

21 The survey encompassed 28.093 respondents in 28 EU Member states.

${ }^{22}$ Combating gender-based violence and challenging gender stereotypes; boosting women's economic empowerment and ensuring equal opportunities in the labour market, including equal pay; and giving both women and men the opportunity to lead and participate in all sectors of the economy and in political life (European Commission, 2020b). 
ing at the local, regional, national and EU levels. What stood out as a goal at the EU level was the "target of $40 \%$ women in senior and middle management by the end of 2019" (European Commission, 2015, p. 14), which was almost completely achieved: by 1 November 2018 the number of female managers reached 39\% (37\% of senior management and $40 \%$ at middle management level) (European Commission, 2019a; 2019b). Parallel to these efforts, the gender balance across all levels, functions and job categories in the European External Action Service (EEAS) has been almost completely achieved with the implementation of an additional strategy - Gender and Equal Opportunity Strategy 2018-2023 (Ibid.).

In the final year of the application of the Strategic engagement for gender equality 2016-2019, the 2019 Report on Equality between women and men in the EU still reported slow progress and a significant under-representation of women in many member states resulting from the "general lack of long-term strategies and the lack of push for change from political parties and governments in many countries" (European Commission, 2019b, p. 33). Despite quotas for the underrepresented sex in some EU member states and the highest representation rate of women in parliaments of all time, in 2019 the parliaments of the EU member states consisted of $32 \%$ women on average. Again, significant discrepancies exist between individual member states, with Sweden and Finland having the highest percentage of female members of their parliaments, while in the parliaments of Hungary, Malta, Cyprus and Croatia women accounted for less than one fifth of the seats (Eurostat, 2019). At the same time, in 2020 women accounted for $39.5 \%$ in the European Parliament, which presented a significant change since 2009 , when the proportion of women was $35 \%$. Again, variations are present among member states, with Finland having $57.1 \%$ women of its members of the European Parliament (MEP), thirteen countries having more than $40 \%$ female MEPs, while in the remaining thirteen members more than $60 \%$ of MEPs were men (European Parliament, 2020).

It is also important to compare the previous (2014-2019) and the current (20192024) composition of the European bureaucracy. In the EU structure from 2014 to 2019 , out of six top positions, ${ }^{23}$ there was only one woman - Federica Mogherini who served as The High Representative of the Union for Foreign Affairs and Security Policy, and as one of five Vice-presidents of the European Commission. Currently, ${ }^{24}$ two of these functions are headed by women: the European Commis-

${ }^{23}$ European Commission (J. K. Juncker), European Council (D. Tusk), European Parliament (M. F. Timmermans), European Central Bank (M. Draghi), The High Representative of the Union for Foreign Affairs and Security Policy (F. Mogherini), Court of Justice of the European Union (K. Lanaerts).

${ }^{24}$ European Commission (U. von der Leyen), European Council (Ch. Michel), European Parliament (D. Sassoli), European Central Bank (Ch. Lagarde), The High Representative of the Union 
sion and the European Central Bank. The European Commission 2014-2019 was comprised of 9 women out of 28 commissioners. The current European Commission (2019-2024) is led by a woman - Ursula von der Leyen as the President, helped by three executive vice-presidents (one female) ${ }^{25}$ and five vice-presidents (including the High Representative for Foreign Affairs and Security Policy), two of which are women. ${ }^{26}$ In the current College of Commissioners from the 27 member countries, there are 12 women - including the president (European Commission, 2020a).

Overall, since 1952 only two women ${ }^{27}$ have served as presidents of the European Parliament (European Parliament, 2019b); since 2009 when the position of the President of the European Council became permanent, following the adoption of the Lisbon treaty, there were three presidents elected, all men; ${ }^{28}$ since 1958 there were 14 presidents of the European Commission, ${ }^{29}$ among them only one woman Ursula von der Leyen. When it comes to the proportion of women in the European Parliament, there has been a constant increase since 1979, when first direct elections of the members were introduced (European Parliament, 2019c). Namely, the proportion of $15.2 \%$ in 1979 has steadily increased to $39.5 \%$ women in the European Parliament in 2019 (European Parliament, 2020). In the period between 1952 and 1979, there were only 31 women in the EP, while today the proportion of women in the EP is above both the world and the EU average for national parliaments (European Parliament, 2019d).

In terms of descriptive representation and the numerical distribution of positions between women and men used as a conceptual framework in this paper, we conducted a comparison of quantitative data among the EU28 at the end of 2019 in order to establish how many women hold one of the following positions at the national level: head of state $^{30} /$ head of government; defence minister; foreign minister; permanent representative to the United Nations (at New York headquarters). Combined, these functions create a total of 139 posts and can serve as an indicator of how member states practice the principles of gender equality in politics, by assigning women to departments dealing with issues of "high politics", having them running for the leading positions in state politics or appointing them as representatives

for Foreign Affairs and Security Policy (J. Borrell), Court of Justice of the European Union (K. Lanaerts).

25 Margrethe Vestager.

26 Dubravka Šuica and Věra Jourová.

27 Out of 32 presidents (including the current president David Sassoli), the only women were Simone Veil (1979-1982) and Nicole Fontaine (1999-2002).

28 Herman Van Rompuy, Donald Tusk and current president Charles Michel.

29 President of the Commission of the European Communities between 1967 and 2009.

${ }^{30}$ Including monarchs in the cases where they exist (for example, Spain, UK or the Netherlands). 
to the multilateral organisations. The results show that only 26 out of 139 posts were held by women. More precisely, there were 2 female monarchs (the UK and Denmark), 3 female heads of state (Croatia, Estonia, Slovakia); 5 prime ministers (Austria, Belgium, Denmark, Finland and Germany); 4 defence ministers (Denmark, France, Germany and Spain); 3 foreign ministers (Bulgaria, Spain and Sweden); and 9 ambassadors to the UN (Czech Republic, Greece, Hungary, Ireland, Italy, Lithuania, Poland, Slovenia, and the UK). These data are in line with the conclusion of the 2019 EU Report on gender equality that "there is also evidence suggesting some gender segregation in allocation of portfolios at cabinet level" (European Commission, 2019b, p. 38).

\section{The United Nations: Still a "Men's Club?}

The UN Charter signed at the San Francisco conference in 1945 presents the founding treaty of the organisation. Its significance is particularly articulated in Article 10, which states that "the obligations to the United Nations prevail over all other treaty obligations" (UN, 1945). This shows the importance of the document for the analysis of gender equality on the global level since the UN numbers 193 states. Then in Article 8, describing the organs of the UN, the eligibility of men and women to participate in any capacity and under the condition of equality in the UN's principal and subsidiary organs was underlined. This shows the UN meets the formal representation criteria. This line is also followed by one of the main purposes attributed to the UN, stated in Articles 1 and 55 of the Charter: "to promote universal respect for human rights and fundamental freedoms, without distinction of any kind, including any distinction as to sex" (Ibid.). However, one needs to mention that the overwhelming majority of state representatives at the San Francisco conference were men. Out of 850 representatives, just four women signed the final text of the Charter. Women from non-western countries such as Brazil, the Dominican Republic, Mexico, Australia etc. played a crucial role in demanding "an explicit reference to women rights in the Charter" (Sator \& Dietrichson, 2020). Particularly one stood out, Brazilian delegate Berta Lutz, who remembers delegates from the United States and United Kingdom telling her "not to ask for anything for women in the Charter, since that would be a very vulgar thing to do" (Ibid.). By having defended women's rights in this context of intimidation, these delegates showed the power of substantive but also symbolic representation, serving as role models for women and girls globally.

Besides the Charter there are several international agreements that guide the work of the UN in terms of gender equality. The cornerstone of all UN women programs is The Convention on the Elimination of All Forms of Discrimination against Women (CEDAW) from 1979, with more than 185 parties (UN, 1979). However, the most progressive blueprint for advocating women rights ever is the Beijing 
Declaration and Platform for Action adopted by governments at the 1995 Fourth World Conference on Women (UN, 1995). The declaration set forth the governments' commitments to enhance women rights. It was further strengthened in 2000 by member states during the twenty-third special session of the General Assembly on "Women 2000: Gender equality, development and peace for the twenty first century" in New York at which a document entitled Further Actions and initiatives to implement the Beijing Declaration and Platform for Action was adopted, as a result of the five-year revision of the Beijing declaration (UN Women, 2000). The pledges to accelerate its implementation were further put forward by its ten, fifteen- and twenty-year reviews in 2005 (UN Women, 2005), 2010 (UN Women, 2010) and 2015 (UN Women, 2015). According to the Resolution adopted by the Economic and Social Council on 12 June 2018 "the Commission on the Status of Women is expected to undertake a review and appraisal of the implementation of Beijing Declaration and the outcomes of the twenty-third special session of the General Assembly at its sixty-fourth session in 2020" (UN Economic and Social Council, 2018). One of its planned activities is to "contribute to realisation of the 2030 Agenda for the Sustainable Development through a gender perspective" (Ibid.).

Approaching the $25^{\text {th }}$ anniversary of the Beijing conference several achievements are visible, such as "an explosion of female firsts and growth in women's representation" during the 90s and ending of gendered voting, except from Vatican (George, 2019). However, challenges remain with projections that women "will not have equal representation in parliaments until 2065 and will comprise only half the world's leaders in 2134" (Ibid.). The challenge is also visible in progress varying regionally, with the "concentration of female heads of state overwhelmingly in Europe" (Ibid.). Furthermore, a formal increase in the number of women in politics does not translate automatically to concrete results, or to put it more simply, descriptive representation does not equal substantial representation. Even when formal representation is guaranteed, "violence and harmful norms can block women's voice and representation" (Ibid.).

In 2000 the UN Security Council Resolution 1325 on women, peace and security was adopted, followed by nine additional resolutions $(1820,1888,1889,1960$, $2106,2122,2242,2467$ and 2493) recognising that war impacts women differently and reaffirming the need to increase women's role in decision-making with regard to conflict prevention and resolution (UN Security Council, 2000). These ten documents "represent a critical framework for improving the situation of women in conflict-affected countries" (UN Women, 2020).

Then, following the Millennium Summit of the United Nations in 2000 eight international development goals were set for the year 2015, one of which (millennium development goal 3) was to "promote gender equality and empower women" 
(UNDP, 2000). The quite ambitious target of "eliminating gender disparity in primary and secondary education" preferably by 2005 and at all levels by 2015 was set (Ibid.). Despite the progress made, women "continue to suffer discrimination and violence in every part of the world" (UN, 2020a) while they also "continue to be underrepresented at all levels of political leadership" (UN, 2020b). Therefore in September 2015 governments united again behind 17 new Sustainable Development Goals and 169 targets that aim "to end poverty, combat inequalities and promote prosperity while protecting the environment by 2030" (UN Women, 2020). Goal 5 (Achieve gender equality and empower all women and girls) is targeted towards "ending all forms of discrimination and violence against women, recognising and valuing unpaid care and domestic work, ensuring women's full and effective participation and equal opportunities for leadership at all levels of decision-making in political, economic and public life, equal rights to economic resources etc." (UN, 2020b). As a supporting document for the implementation of the Beijing Declaration and 2030 Agenda for Sustainable Development, the UN adopted the $U N$ Women Strategic Plan 2018-2021 outlining five strategic priorities: "implementing a comprehensive set of global norms, policies and standards on gender equality and the empowerment of women; women leading, participating and benefiting equally from governance systems; women having income security, decent work and economic autonomy; women and girls living free from all forms of violence and women contributing to building sustainable peace and resilience as well as benefiting from the prevention of natural disasters and conflicts as well as humanitarian action" (UN Women, 2018b).

The United Nations are striving to ensure gender parity which has been reiterated in several General Assembly Resolutions. In 1995 the Beijing Declaration and Platform for Action "set a goal of 50/50 gender balance in managerial and decisionmaking positions by the year 2000" (UN, 1995). However, 2020 will mark Beijing +25 anniversary commemoration and serve as a reminder that the goal is long overdue and that progress must be accelerated (UN Women, 2019).

During the mandate of the Secretary-General Ban Ki-moon, several steps were taken towards strengthening the role of women, starting with the development of his system-wide strategy on gender parity. There has been more transparency accomplished, with the UN's public website showing current parity data for the UN secretariat, a task force responsible for undertaking wide consultations on gender parity was created, an effort was made to strengthen accountability by integrating gender parity goals in senior leadership compacts, strengthened efforts have been taken and coordinated by more than 200 gender focal points and human resources experts across the system, as well as more than fifty concrete recommendations were created to guide the system in achieving the strategy's goals (Ibid.). With the 
exception of these achievements, Ban Ki-moon admitted that progress in the field of peace operations has been slow. According to his report and data as of 31 December 2017 the representation of women in the UN system in the professional and higher categories was $44.2 \%$. During the reported period of 1 January 2016 to 1 December 2017 the overall representation of women was negatively correlated with seniority. However, between 2016 and 2017 the percentage of women in ungraded level (Assistant Secretary general, director general, deputy director general, assistant director general, Under-Secretary General and secretary general) increased from 25.9 to $33.6 \%$. This dramatic increase reversed a trend of declines since 2010, achieving the highest level of representation to date. Since the previous report from 2017 the representation of women increased by $2.3 \%$ in the director category and $1.4 \%$ in the professional category, while representation among national professional officers remained unchanged at $44 \%$. Representation in general and field services categories decreased by $1.7 \%$ and $0.5 \%$ while the category with the lowest representation of women is field service at $27 \%$ (Ibid.). In $18 \mathrm{UN}$ entities the representation of women was between 40 and $49 \%$, while in 11 that figure was below $40 \%$. Those entities with the lowest representation of women (less than $40 \%$ ) predominantly have mandates in technical fields (UNU, UNITAR, WMO, ITU, ICSC, UNOPS, UNIDO, IAEA, UPU, ICAO and UNICC ${ }^{31}$ with only $18.6 \%$ ). The highest representation is in UN-Women (80.2\%), ICJ (55.9\%), UNSSC (55.0\%) and UNWTO ${ }^{32}(52.3 \%)$. This data illustrates "the persistent occupational segregation within the UN system" (Ibid.). It is important to notice that the overall representation of women in the professional and higher categories in the UN system increased from $42.8 \%$ on 31 December 2015 to $44.2 \%$ on 31 December 2017. Despite this encouraging trend there is a negative correlation between the representation of women and seniority, although recent gains at the Under-Secretary General and Assistant Secretary general levels are starting to change the trend (Ibid.). The major challenge is still presented with the low representation of women in peace operations.

Out of 13 candidates for the position of the UN Secretary-General in 2016, seven were women with impressive resumes. According to the BBC (2016a) some were "arguably more experienced than elected former Portuguese prime minister

31 UNU - United Nations University, UNITAR - United Nations Institute for Training and Research, WMO - World Meteorological Organization, ITU - International Telecommunication Union, ICSC - International Civil Service Commission, UNOPS - United Nations Office for Project Services, UNIDO - United Nations Industrial Development Organization, IAEA - International Atomic Energy Agency, UPU - Universal Postal Union, ICAO - International Civil Aviation Organization, UNICC - United Nations International Computing Centre.

${ }^{32}$ UN-Women - United Nations Entity for Gender Equality and the Empowerment of Women, ICJ - International Court of Justice, UNSSC - United Nations System Staff College, UNWTO United Nations World Tourism Organisation. 
Antonio Guterres", who also served as the head of the organisation's refugee agency (UNHCR). ${ }^{33}$ Even then outgoing Secretary-General Ban Ki-moon highlighted that it was "high time for a female head" (BBC News, 2016b). Namely, the UN had eight male leaders in more than 70 years of existence. Despite "numerous qualified candidates from all regions of the world" (Equality now.org, 2016) there has never been a woman Secretary-General.

According to Article 97 of the United Nations Charter (1945) "the Secretary General is appointed by the General Assembly upon the recommendation of the Security Council", which at the time of election was a male club with only one woman, US representative Samantha Power, serving as that member country's ambassador to the UN. At the beginning of 2020 out of 15 permanent and non-permanent representatives to the UN Security Council, there were three women: Inga Rhonda King from Saint Vincent and the Grenadines, Karen Pierce from the UK and Kelly Craft from the United States. The highest number of women in the Security Council ever was recorded in September 2014 - with six out of fifteen (Deen, 2019).

Women and the Eastern European group were favoured during the 2016 elections for Secretary-General, as they never held the office, however the candidate who won is neither female nor from Eastern Europe. Argentina's foreign minister Susana Malcorra, who contended for the position, claimed that "gender remains an issue in the election of a Secretary General" (Lynch, 2016). During the election process a group consisting mostly of academics "The Campaign to Elect a Woman UN Secretary General" supported the female candidates. According to Jean Krasno, a lecturer on international affairs and chair of the Campaign: "Fourteen men on the Security Council and one woman, Samantha Power, couldn't envision a women at the top" (Ibid.). According to Malcorra the "Security Council is a boys club" (Ibid.).

In 2018 Maria Fernanda Espinosa Garces, foreign minister of Ecuador, was elected President of the UN General Assembly (PGA), as only the fourth woman in history, ahead of another female candidate, Mary Flores Flake of Honduras. She dedicated her election to "all women in the world of politics who face attacks by the media and other politicians marked by discrimination and machismo" (UN News, 2018). The first PGA was India's Vijaya Lakshmi Pandit in 1953, the second Libe-

${ }^{33}$ Among others, they included the director-general of the United Nations Educational, Scientific and Cultural Organisation - UNESCO (Irina Bokova), former prime minister of New Zealand and administrator of UNDP (Helen Clark), executive Secretary of the United Nations Framework Convention on Climate Change (Christiana Figueres), acting prime Minister of Moldova (Natalia Gherman), acting minister of foreign affairs and worship of the Republic of Argentina and former chef de Cabinet to the Secretary-General of the UN (Susana Malcorra), former Croatian minister of foreign and European affairs (Vesna Pusić) and former European Commissioner for International Cooperation, Humanitarian Aid and Crisis Response and for the Budget and Human Resources (Kristalina Georgieva). 
ria's Angie Brooks in 1969, while Haya Rashed Al Khalifa of Bahrain became the third woman PGA in 2016 (Ibid.).

As of October 2019 there is a record number of 50 women out of 193 permanent representatives in the UN General Assembly (PRUN). However, this is low compared to the 140 men (the remaining three posts are not considered the rank of PRUN). According to Barbara Croassette, the Nation's United Nations Correspondent, more female diplomats does not necessarily mean more gender equality (Deen, 2019). This descriptive and formal representation would turn into substantial and symbolic only if UN member states would choose the most competent women for the highest positions within organisations. Furthermore, the joint actions of female ambassadors "would draw more attention and result with policy changes and more focus on issues directly related to women's empowerment and equality, like Goal 5 of SDG". Therefore, women ambassadors should "turn the numerical enhancement into an effective coalition" (Ibid.)

In terms of descriptive representation and the numerical distribution of positions between women and men used as a conceptual framework for this paper, we analysed how many women take part in the main organs of the UN: General Assembly President (0), Permanent Representatives to UN (50 out of 193), Security Council member states representatives (3 out of 15), President of the Economic and Social Council (1), International Court of Justice Members (3 out of 15, with male president), Secretariat - Secretary General (0). In 2020, the Deputy Secretary General is a woman, while the Senior Management Group which brings together leaders of United Nations departments, offices, funds and programs has 29 women out of 46 members. The following numbers are related to women at the leading positions in the UN entities: three out of six leading positions in funds and programs, three out of fifteen leading positions in specialised agencies, four out of eight leading positions in other entities and bodies. All the numbers presented in the research on women representation in the United Nations show several positive trends, particularly related to percentage of women acting as Under-Secretary General and Assistant Secretary general, in specialised programs, funds and agencies, as well as their leading structures and those related to the number of female permanent representatives to the UN. However, there has never been a female Secretary-General, while women are currently underrepresented in the Security Council, within entities with mandates in technical fields as well as within peace operations. Although formal criteria for representation are met at the level of Secretary-General, history did not offer us the opportunity to evaluate women at this highest position. From its founding, the United Nations have recognized gender equality as a part of their mission, which is evident from all analysed strategic documents, however many challenges remain. One of the most symbolic steps forward would be to change the UN's reputation of men's club and break the glass ceiling in the United Nations: the top job of Secretary-General. 


\section{Conclusion}

Despite the progress that has been made throughout the $20^{\text {th }}$ and $21^{\text {st }}$ centuries, the underrepresentation of women in "high politics" and international organisations is still observable. Even in the West, admitting women to traditional male domains, such as diplomacy and security, has been introduced with caution. For a long time, women had been almost completely absent from decision-making processes at the highest level.

Considering the four dimensions of women's political representation, in this paper the focus has been on the formal and descriptive ones. By applying this type of analysis, it is possible to establish whether all conditions for equal representation have been met, what is the number of women elected at the highest level and whether in different settings gender equality has been actively promoted as a positive value that can be beneficial for the political community in general. Although numbers do not necessarily imply any substantive changes, nor speak about the content of women's political engagement, they can clearly show some trends than could be further analysed and related to different policies. If a woman was elected Secretary-General of UN, this would serve as a great starting point for comparisons of UN policies in various fields during her mandate and the mandates of her male counterparts. This is just an example of how formal and descriptive representation may serve as variables in interpreting the symbolic and substantive representation of women in politics.

In terms of normative conditions, our analysis shows that there is quite an extensive set of international norms laid down in founding and constitutive documents of international entities whose aim is to enable gender equality generally and in politics particularly. Additionally, if not globally, at least in the case of European states, gender equality is a constitutional category, from which the rest of national legislation for gender equality is developed. However, the research has also demonstrated that there are still clear examples of discrepancy between the principles laid down in numerous legally binding documents that have been signed and ratified by the majority of states globally and their practices towards women's inclusion in politics. This phenomenon can be observed both at the national level and within multilateral entities. However, one cannot say that these documents did not produce any significant results in terms of gender equality. Quite the contrary, at this point the participation of women in politics is higher than ever before, taking into account significant regional differences. Regardless of that fact, full gender equality is still a rare example, which is clear from our analysis.

Although there are significant changes visible and efforts made to achieve gender equality at the EU level (i.e. EEAS, European Commission), there are chal- 
lenges remaining (i.e. women's representation in the European Parliament). At the EU member state level there are significant variations between countries, which indicates that a normative framework envisaging the removal of formal obstacles for women being elect for the parliament, has not been equally visible nor translated into practice. This is particularly highlighted in our paper by the numerical distribution of positions between women and men at the highest levels (head of state / head of government, defence minister, foreign minister and representative to the UN) of the EU member states as well as by gender segregation in the allocation of different portfolios.

The analysis also shows that the normative framework dealing with gender equality has been very much present within the United Nations from its founding. Over the years it has been further developed within various resolutions, declarations, strategic plans and as part of Millennium Development Goals, as well as Sustainable Development Goals. Although there has been significant progress achieved in strengthening the role of women (system-wide strategy, more transparency, gender focal points, recommendations in achieving the strategy), progress in some fields is still quite slow. The results show the lowest representation of women in UN entities with mandates in technical fields as well as in the field of peace operations. Here we can trace a similar pattern as the one noticed within the EU. While the number of women who participated in the process of UN Secretary-General Election in 2016 is encouraging, the fact that the UN as an agenda setter in terms of human rights and gender equality never had women at this top position testifies that the glass ceiling has not been reached yet, let alone broken.

\section{REFERENCES}

Agencia Estatal Boletín Oficial del Estado. (1978). Constitution of Spain. Retrieved from https://www.boe.es/legislacion/documentos/ConstitucionINGLES.pdf

Aggestam, K., Bergman, R. A., \& Kronsell, A. (2019). Theorising Feminist Foreign Policy. International Relations, 33 (1): 23-39. Retrieved from https://journals.sagepub.com/doi/full/10.1177/0047117818811892

BBC News. (2016a). Why wasn't a woman elected as UN secretary general? (6 October). Retrieved from https://www.bbc.com/news/world-europe-37574307

BBC News. (2016b). Ban Ki-moon: 'High time'the UN had a female leader (16 August). Retrieved from https://www.bbc.com/news/world-37092328

Beck, D. (1978). Equal Pay and the Implementation of Article 119 of the Treaty of Rome. Irish Jurist, 13 (1): 112-131. Retrieved from https://www.jstor.org/stable/i40167178 
Britannica. (2019). Pragmatic Sanction of Emperor Charles VI. Retrieved from https:// www.britannica.com/topic/Pragmatic-Sanction-of-Emperor-Charles-VI

Buzan, B., Wæver, O. \& de Wilde, J. (1998). Security - A New Framework for Analysis. Lynne Rienner Publishers. London, England and Boulder, CO.

Bühlmann, M., Schädel, L. (2012). Representation Matters: The Impact of Descriptive Women's Representation on the Political Involvement of Women. Journal of Representative Democracy, 48 (1): 101-114.

Chapnick, A. (2019). The Origins of Canada's Feminist Foreign Policy. International Journal: Canada's Journal of Global Policy Analysis, 74 (2): 191-205. Retrieved from https://journals.sagepub.com/doi/abs/10.1177/0020702019850827?icid=int. sj-abstract.similar-articles.2\&journalCode $=\mathrm{ijxa}$

Chattopadhyay, R., Duflo, E. (2004). Women as Policy Makers: Evidence from a Randomized Policy Experiment in India. Econometrica, 72 (5): 1409-1443.

Childs, S., Krook, M. L. (2008). Theorizing Women's Political Representation: Debates and Innovations in Empirical Research. Femina Politica, 17 (2): 20-29.

Corcos, C. A. (2012). From Agnatic Succession to Absolute Primogeniture: the Shift to Equal Rights of Succession to Thrones and Titles in the Modern European Constitutional Monarchy. Michigan State Law Review, 2012 (1): 1587-1670. Retrieved from https://digitalcommons.law.msu.edu/cgi/viewcontent.cgi?article=1066\&context=lr

Council of the European Union. (2011). European Pact for gender equality for the period 2011 - 2020. Retrieved from https://eur-lex.europa.eu/legal-content/EN/TXT/ $\mathrm{PDF} /$ ?uri=CELEX:52011XG0525(01)\&from $=\mathrm{EN}$

Deen, T. (2019, October 8). UN Women Ambassadors Rise to New Heights But Fall Short of Gender Parity. Retrieved from http://www.ipsnews.net/2019/10/un-women-ambassadors-rise-new-heights-fall-short-gender-parity/

Demel, J. A. (2017). Female "Diplomats" in Europe from 1815 to the Present. Encyclopédie pour une histoire nouvelle de l'Europe. Retrieved from https://ehne.fr/ en/encyclopedia/themes/gender-and-europe/gender-citizenship-in-europe/female$\% \mathrm{E} 2 \% 80 \% 9$ Cdiplomats $\% \mathrm{E} 2 \% 80 \% 9 \mathrm{D}$-in-europe-1815-present

DG JUST. (2019). Justice, Consumers and Gender Equality. Retrieved from https:// ec.europa.eu/info/departments/justice-and-consumers_en

Eagly, A. H., Wood, W. (2013). The nature-nurture debates: 25 years of challenges in the psychology of gender. Perspectives on Psychological Science, 8 (3): 340-357. Retrieved from https://dornsife.usc.edu/assets/sites/545/docs/Wendy_Wood_Research_Articles/Gender_Differences_in_Social_Behavior/eagly.wood.2013.nature-nurture_debates.pdf

European Commission. (2010). Strategy for equality between women and men 20102015. Retrieved from https://op.europa.eu/en/publication-detail/-/publication/ c58de824-e42a-48ce-8d36-a16f30ef701b/language-en 
European Commission. (2015). Strategic engagement for gender equality 2016-2019. Retrieved from https://ec.europa.eu/anti-trafficking/eu-policy/strategic-engagement-gender-equality-2016-2019_en

European Commission. (2017). Gender equality 2017. Special Eurobarometer 465. Retrieved from https:/ec.europa.eu/commfrontoffice/publicopinion/index.cfm/Survey/getSurveyDetail/instruments/SPECIAL/surveyKy/2154

European Commission. (2019a). Women in management: Juncker Commission exceeds $40 \%$ target. Retrieved from https://ec.europa.eu/commission/presscorner/detail/en/ IP_19_6139

European Commission. (2019b). Report on Equality between women and men in the EU. Retrieved from https://op.europa.eu/en/publication-detail/-/publication/f3dd12747788-11e9-9f05-01aa75ed71a1/

European Commission. (2020a). The Commissioners - The European Commission's political leadership. Retrieved from https:/ https://ec.europa.eu/commission/commissioners/2019-2024 en

European Commission. (2020b). A Union of Equality: Gender Equality Strategy 2020-2025. Retrieved from https://eur-lex.europa.eu/legal-content/EN/ TXT/?uri=CELEX\%3A52020DC0152

European External Action Service (EEAS). (2017). Gender and Equal Opportunity Strategy 2018-2023. Retrieved from https://eurotradeunion.eu/documents/WGgender. pdf

European Institute for Gender Equality (EIGE). (2020). Gender Equality Index 2020: Digitalisation and the future of work. Retrieved from https://gender-spear.eu/assets/ content/EIGE\%20Index\%202020.pdf

European Parliament. (2019a). Promoting equality between women and men, Briefing (EU policies - Delivering for citizens). Retrieved from https://www.europarl.europa.eu/RegData/etudes/BRIE/2018/628272/EPRS_BRI(2018)628272_EN.pdf

European Parliament. (2019b). Former presidents of the EP. Retrieved from https:// www.europarl.europa.eu/the-president/en/the-presidency

European Parliament. (2019c). The European Parliament: historical background. Retrieved from https://www.europarl.europa.eu/ftu/pdf/en/FTU_1.3.1.pdf

European Parliament. (2019d). Proportion of Women and Men in the European Parliament. Retrieved from https://www.europarl.europa.eu/news/en/headlines/ society/20190226STO28804/women-in-the-european-parliament-infographics

European Parliament. (2020). Women in parliaments - at a glance. Retrieved from https://www.europarl.europa.eu/RegData/etudes/ATAG/2020/646189/EPRS ATA(2020)646189_EN.pdf

Eurostat. (2019). 1 in 3 parliament and government members are women. Retrieved from https://ec.europa.eu/eurostat/web/products-eurostat-news/-/EDN-20200308-1 
Equality now.org. (2016). Global: It's Past Time for a Woman UN Secretary General. Retrieved from https://www.equalitynow.org/global_it_s_past_time_for_a_woman_un_secretary_general?locale $=$ ar

Foreign and Commonwealth Office. (2018). Women and the Foreign Office, History notes: Issue 20. Retrieved from https://assets.publishing.service.gov.uk/government/uploads/system/uploads/attachment_data/file/747797/Women_in_Diplomacy_History_Note_2nd_Edition_.pdf

Fritsche, C. (2002). Opportunities and Challenges for Women in Diplomacy. Lecture at Princeton University. Retrieved from https://lisd.princeton.edu/sites/lisd2017/files/ Fritsche_Lecture.pdf

Geiger, A. W., Kent, L. (2017, March 8). Number of women leaders around the world has grown, but they're still a small group. Pew Research Center. Washington DC. Retrieved from http://www.pewresearch.org/fact-tank/2017/03/08/women-leadersaround-the-world/

George, R. (2019, November 18). Many gains, but many miles to go: women in power since 1995. Retrieved from http://www.odi.org/blogs/many-gains-many-miles-gowomen-power-1995

Government of Sweden. (2019a). A feminist government ensures that decisions promote gender equality. Retrieved from https://www.government.se/4938bc/globalassets/ government/bilder/socialdepartementet/tidigare-politikomraden-och-politiker/gender-equality/information-material--a-feminist-government-march-2019.pdf

Government of Sweden. (2019b). Sweden's Feminist Foreign Policy - Handbook. Retrieved from https://www.government.se/4ae557/contentassets/fc115607a4ad4bca913cd8d11c2339dc/handbook---swedens-feminist-foreign-policy.pdf

Government of Sweden. (2020). The Swedish Government. Retrieved from https://www. government.se/4af8a1/contentassets/8dde51a0510c4344bec983aea222f206/sveriges-regering-faktablad.pdf

Guerrero Witt, M., Wood, W. (2010). Self-regulation of Gendered Behavior in Everyday Life. Sex Roles, 62 (9): 635-646. Retrieved from https://dornsife.usc.edu/assets/ sites/545/docs/Wendy_Wood_Research_Articles/Gender_Differences_in_Social_ Behavior/guerrero-witt.wood.2010_self-regulation_of_gendered_behavior_in_ everyday_life.pdf

Hudson, N. F. (2010). Gender, Human Security and the United Nations: Security Language as a Political Framework for Women. Political Science Faculty Publications. Paper 53. University of Dayton. Dayton, OH. Retrieved from https://ecommons. udayton.edu/cgi/viewcontent.cgi?article $=1052 \&$ context=pol_fac_pu

Human Rights Watch. (2015). Saudi Arabia: Landmark Elections for Women. Retrieved from https://www.hrw.org/news/2015/12/11/saudi-arabia-landmark-elections-women

Inter-Parliamentary Union \& UN Women. (2020). Women in Politics 2020 (Situation on 1 January 2020). Retrieved from https://www.ipu.org/resources/publications/ 
infographics/2020-03/women-in-politics-2020\#: :text=The\%20IPU\%2DUN\%20 Women\%20map,and\%20women\%20MPs\%20and\%20ministers

Iwanaga, K. (2008). Women and Politics in Asia: A Comparative Perspective. In K. Iwanaga (Ed.), Women's Political Participation and Representation in Asia: Obstacles and Challenges (pp. 1-22). NIAS. Copenhagen.

Journal de Monaco. (2002). Constitution of the Principality. Retrieved from https:// en.gouv.mc/Government-Institutions/Law-and-Legislation/Journal-de-Monaco

Krause, K., Williams, M. C. (1996). Broadening the Agenda of Security Studies: Politics and Methods. Mershon International Studies Review, 40 (2): 229-254. Retrieved from https://www.jstor.org/stable/222776?read-now=1\&refreqid=excelsior\%3Ad6 54be62cb88d2012252379b7a753166\&seq=1\#page_scan_tab_contents

Lloren, A. (2019). Switzerland: Direct Democracy and Women's Political Participation. In S. Franceschet, M. L. Krook, \& N. Tan (Eds.), The Palgrave Handbook of Women's Political Rights (pp. 155-167). Palgrave Macmillan. London. Retrieved from https://link.springer.com/chapter/10.1057/978-1-137-59074-9_11

Lore, G. A. (2016). Women's Descriptive and Substantive Political Representation: The Role of Political Institutions [PhD Thesis, University of British Columbia, Canada]. Retrieved from https://pdfs.semanticscholar.org/e476/335a021b3b50 0e1f2adc687d88288b1881af.pdf?_ga=2.128336463.250486832.15793774531266370583.1579377453

Lynch, C. (2016, October 5). U.N's "Steel Ceiling” Blocks First Woman Secretary-General. Foreign Policy. Retrieved from https://foreignpolicy.com/2016/10/05/u-n-ssteel-ceiling-blocks-first-woman-secretary-general/?wp_login_redirect $=0$

Mansbridge, J. J. (1999). Should Blacks Represent Blacks and Women Represent Women? A Contingent 'Yes'. Journal of Politics, 61 (3): 628-657.

NBC News. (2020). Pope Francis names first woman to senior Vatican diplomatic post. Retrieved from https://www.nbcnews.com/news/religion/pope-francis-names-firstwoman-senior-vatican-diplomatic-post-n1116586

Official Journal of the EU. (1978). Directive on equal treatment of men and women in statutory schemes of social security (79/7/EEC). Retrieved from https://eur-lex.europa.eu/legal-content/EN/TXT/?uri=LEGISSUM\%3Ac10907

Official Journal of the EU. (1992). Pregnant Workers' Directive (92/85/EEC). Retrieved from https://eur-lex.europa.eu/legal-content/EN/TXT/?uri=celex\%3A31992L0085

Official Journal of the EU. (2004). Directive on equal treatment of men and women in the access to and the supply of goods and services (2004/113/EC). Retrieved from https://eur-lex.europa.eu/legal-content/EN/TXT/?uri=celex\%3A32004L0113

Official Journal of the European Union. (2006). Directive on the implementation of the principle of equal opportunities and equal treatment of men and women in matters of employment and occupation (2006/54/EC). Retrieved from https://eur-lex. europa.eu/legal-content/EN/TXT/?uri=CELEX\%3A32006L0054 
Official Journal of the EU. (2006). Directive on the implementation of the principle of equal opportunities and equal treatment of men and women in matters of employment and occupation - Recast Directive (2006/54/EC). Retrieved from https://eurlex.europa.eu/legal-content/EN/TXT/?uri=CELEX\%3A32006L0054

Official Journal of the EU. (2010a). Directive on the application of the principle of equal treatment between men and women engaged in an activity in a self-employed capacity (2010/41/EU). Retrieved from https://eur-lex.europa.eu/legal-content/EN/ TXT/?uri=celex\%3A32010L0041

Official Journal of the EU. (2010b). Directive implementing the revised Framework Agreement on parental leave (2010/18/EU). Retrieved from https://eur-lex.europa. eu/legal-content/EN/TXT/?uri=CELEX\%3A32010L0018

Official Journal of the European Union. (2012a). Consolidated version of the Treaty on European Union. Retrieved from https://eur-lex.europa.eu/legal-content/EN/ TXT/?uri=celex\%3A12012M\%2FTXT

Official Journal of the European Union. (2012b). Charter of Fundamental Rights of the European Union. Retrieved from https://eur-lex.europa.eu/legal-content/EN/TXT/ PDF/?uri=CELEX:12012P/TXT\& from=EN

Official Journal of the European Union. (2016). Consolidated version of the Treaty on the Functioning of the European Union. Retrieved from https://eur-lex.europa.eu/ legal-content/EN/TXT/PDF/?uri=CELEX:12016E/TXT\&from=EN

OpenCanada.org. (2019). Is the Future of Foreign Policy Feminist? Centre for International Governance Innovation. Retrieved from https://www.opencanada.org/indepth/future-foreign-policy-feminist/

Paxton, P., Hughes, M. M. (2019). The Political Representation of Women over Time. In S. Franceschet, M. L. Krook \& N. Tan (Eds.), The Palgrave Handbook of Women's Political Rights (pp. 33-51). Palgrave Macmillan. London.

Pitkin, H. F. (1967). The Concept of Representation. University of California. Berkeley.

Rahman-Figueroa, T. (2020). Celebrating the Rise of Women in Diplomacy. Retrieved from https://www.grassrootdiplomat.org/news/celebrating-the-rise-of-women-indiplomacy

Ravi Kumar, V. (2002). Women in Political Decision Making. India International Centre Quarterly, 29 (1): 106-114. Retrieved from https://www.jstor.org/ stable/23005801 ?read-now=1\&refreqid=excelsior\%3 Ae6049a 7 aff53742db0871c2 9d1641ad5\&seq=1\#page_scan_tab_contents

Rawlings, M. (2016, August 18). Women in diplomacy: Look how far we've come. The Interpreter. Retrieved from https://www.lowyinstitute.org/the-interpreter/womendiplomacy-look-how-far-weve-come

Sapiro, V. (1982). Private Costs of Public Commitments or Public Costs of Private Commitments? Family Roles Versus Political Ambition. American Journal of Political Science, 26 (2): 265-279. 
Sator, F., Dietrichson, E. (2020). Women in the UN Charter. SOAS University of London, Centre for International Studies and Diplomacy. London. Retrieved from https:// www.soas.ac.uk/cisd/research/women-in-diplomacy/women-in-the-un-charter/

Senden, L., Timmer, A. (2019). Gender Equality Law in Europe - How are EU laws transposed into national law in 2018? European Commission - DG for Justice and Consumers. Retrieved from https://op.europa.eu/en/publication-detail/-/ publication/9b101483-3a44-11e9-8d04-01aa75ed71a1

Stockemer, D. (2007). Why are there Differences in the Political Representation of Women in the 27 Countries of the European Union? Perspectives on European Politics and Society, 8 (4): 476-493. Retrieved from https://www.tandfonline.com/doi/pdf/1 $0.1080 / 15705850701640884$ ?needAccess $=$ true

Succession. (2019). The Home of the Royal Family. London. Retrieved from https:// www.royal.uk/succession

Sveriges Riksdag. (2016). Constitution of Sweden - the Fundamental Laws and the Riksdag Act. Retrieved from https://www.riksdagen.se/globalassets/07.-dokument--lagar/the-constitution-of-sweden-160628.pdf

Swers, M. L. (1998). Are Women More Likely to Vote for Women's Issue Bills Than Their Male Colleagues? Legislative Studies Quarterly, 23 (3): 435-448.

Swiss Fact: some Swiss women had to wait until 1991 to vote. (2017). Retrieved from https://lenews.ch/2017/11/25/swiss-fact-some-swiss-women-had-to-wait-until1991-to-vote/

Thompson, L., Asquith, C. (2018). One Small Step for Feminist Foreign Policy. Retrieved from https://foreignpolicy.com/2018/09/20/one-small-step-for-feminist-foreign-policy-women-canada/

Tickner, J. A. (1992). Gender in International Relations - Feminist Perspectives on Achieving Global Security. Columbia University Press. New York.

Towns, A., Niklasson, B. (2017). Gender, International Status, and Ambassador Appointments. Foreign Policy Analysis, 13 (3): 521-540. Retrieved from https://academic. oup.com/fpa/article/13/3/521/2625550.

Tremblay, M. (2007). Democracy, Representation and Women: A Comparative Analysis. Democratization, 14 (4): 533-553. Retrieved from https:/www.tandfonline.com/ doi/pdf/10.1080/13510340701398261?needAccess=true

UN. (1945). Charter of the United Nations. Retrieved from https:/www.un.org/en/charter-united-nations/

UN. (1979). Convention on the Elimination of All Forms of Discrimination against Women. Retrieved from https://www.un.org/womenwatch/daw/cedaw/text/econvention.htm

UN. (1995). Beijing Declaration and Platform for Action. Retrieved from https://www. un.org/womenwatch/daw/beijing/pdf/BDPfA\%20E.pdf 
UN. (2020a). Goal 5: Achieve gender equality and empower all women and girls. Retrieved from https://www.un.org/sustainabledevelopment/gender-equality/

UN. (2020b). Goal 5: Achieve gender equality and empower all women and girls - Overview. Retrieved from https://sdgacademy.org/goal/gender-equality/

UNDP. (2000). Millennium Development Goals. Retrieved from https://www.undp.org/ content/undp/en/home/sdgoverview/mdg_goals/

UN Economic and Social Council. (2018). Future organization and methods of work of the Commission on the Status of Women. Retrieved from https://undocs.org/en/E/ $\mathrm{RES} / 2018 / 8$

UN News. (2018). Woman elected as head of UN General Assembly for fourth time in 73 years. Retrieved from https://news.un.org/en/gallery/534371

UN Security Council. (2000). Resolution 1325 Adopted by the Security Council at its $4213^{\text {th }}$ meeting on October 2000. Retrieved from https://undocs.org/en/S/ RES/ $1325 \% 282000 \% 29$

UN Women. (2000). Five-year Review of the Implementation of the Beijing Declaration and Platform for Action (Beijing+5) held in the General Assembly, 5-9 June 2000. Retrieved from https://www.un.org/womenwatch/daw/followup/beijing+5.htm

UN Women. (2005). Ten-year review and Appraisal of the implementation of the Beijing Declaration and Platform for Action and the outcome of the twenty-third special session of the General Assembly held during the forty-ninth session of the CSW from 28 February to 11 March 2005. Retrieved from https://www.un.org/womenwatch/ daw/Review/english/49sess.htm

UN Women. (2010). 15-year review of the Implementation of the Beijing Declaration and Platform for Action (1995) and the outcomes of the twenty-third special session of the General Assembly (2000). Retrieved from https://www.un.org/womenwatch/ daw/beijing15/

UN Women. (2015). The Beijing Platform for Action Turns 20. Retrieved from https:// beijing20.unwomen.org/en

UN Women. (2018a). Women and democracy: What does it take to change politics as usual? Retrieved from https://www.unwomen.org/en/news/stories/2018/9/compilation-international-day-of-democracy

UN Women. (2018b). UN Women Strategic Plan 2018-2021. Retrieved from https:// www.unwomen.org/en/executive-board/documents/strategic-plan-2018-2021

UN Women. (2019). Improvement in the status of women in the United Nations system: Report of the Secretary-General. Retrieved from https://digitallibrary.un.org/ record/3825109? 1 n=en

UN Women. (2020). Guiding Documents. Retrieved from https:/www.unwomen.org/en/ about-us/guiding-documents 
Vagnoux, I. (2015). Introduction: North American Women in Politics and International Relations. European Journal of American Studies, 10 (1): 1-9.

Wängnerund, L. (2009). Women in Parliaments: Descriptive and Substantive Representation. Annual Review of Political Science, 12: 51-69. Retrieved from https://www. annualreviews.org/doi/abs/10.1146/annurev.polisci.11.053106.123839

Wood, M. M. (2015). Wives, Clerks and "Lady Diplomats": The Gendered Politics of Diplomacy and Representation in the U.S. Foreign Service, 1900-1940. European Journal of American Studies, 10 (1): 1-12.

Wood, W., Eagly, A. H. (2015). Two Traditions of Research on Gender Identity. Sex Roles, 73 (11-12): 461-473. Retrieved from https://dornsife.usc.edu/assets/sites/545/docs/ Wood._Eagly.Two_Traditions.2015.pdf

Young, I. M. (1990). Justice and the Politics of Difference. Princeton University Press. Princeton, NY.

Zungura, M., Nyemba, E., Mutasa, F. \& Muronza, C. (2013). The relationship between democracy and women participation in politics. Journal of Public Administration and Governance, 3 (1): 168-176. Retrieved from http://www.macrothink.org/journal/index.php/jpag/article/view/3516

Mailing Addresses:

Ružica Jakešević, Faculty of Political Sciences, University of Zagreb, Lepušićeva 6, 10000 Zagreb.E-mail: ruzica.jakesevic@fpzg.hr

Đana Luša, Faculty of Political Sciences, University of Zagreb, Lepušićeva 6, 10000 Zagreb.E-mail: dana.lusa@fpzg.hr 